(Accepted for publication by Gender Work and Organization, Vol 11 (2): 2004)

Dangerous Work: The Gendered Nature of Bullying in the Context of Higher Education

\author{
Ruth Simpson \\ Brunel Business School \\ Brunel University \\ Uxbridge, UB8 3PH \\ R.Simpson@brunel.ac.uk
}

Claire Cohen

Cornwall Business School

Penhaligon Building

Cornwall College

Pool, Redruth

Cornwall

TR15 3RD

Claire.Cohen@cornwall.ac.uk 


\title{
Dangerous Work: The Gendered Nature of Bullying in the Context of Higher Education
}

\begin{abstract}
This paper discusses results from a research project which set out to investigate gender differences in the nature and experience of bullying within the higher education sector. Gender differences emerged in the form and perception of bullying as well as in target response. Results also indicate that, irrespective of gender, bullies can capture and subvert organizational structures and procedures (official hierarchies, mentoring systems, probationary reviews) to further their abuse of the target and to conceal aggressive intent. These outcomes are discussed in relation to gendered assumptions behind management practices and in relation to the masculinist ethic that underpins many higher education management initiatives. Overall, results indicate that bullying cannot be divorced from gender and that such behaviour needs to be seen in a gendered context.
\end{abstract}

Key words: bullying, gender, higher education 


\section{Introduction}

Over the past decade, workplace bullying has increasingly become the subject of academic and popular interest (McMahon, 2000). This may in part be attributed to the energetic work of those who have experienced workplace bullying (e.g. Field, 1997) and who are determined to address the secrecy that has often surrounded the subject. Other popular or academic writers have attempted to raise awareness of workplace bullying and have recommended measures to overcome it (e.g. Adams, 1992; Carr, 2000). Despite this work, and despite evidence of the pervasiveness of bullying in organizations (Hoel and Cooper, 2000; Rayner, 1997; Quine, 1999) and of the psychological harm suffered by targets of such behaviour (Gutek and Koss, 1993), bullying does not feature regularly in academic literature. Theoretical and conceptual frameworks are consequently underdeveloped. At the same time, while literature on sexual harassment has drawn extensively from feminist theory and has located such behaviour within a broad framework of gendered power relations (e.g. Cockburn, 1991; MacKinnon, 1979), bullying is generally not constructed as gendered (Hearn and Parkin, 2001). Our study, which was located within the context of higher education and backed in part by the Association of University Teachers (AUT), addresses this research gap by exploring the importance of gender in the perception and experience of bullying.

A possible contributor to the underdevelopment of research is the general absence of distinction in the literature between bullying and other forms of workplace harassment and a lack of agreement on the definition of bullying (Rayner et al, 1999). The conflation 
of bullying with the more general 'harassment' has tended to hide certain distinctive features that could have inhibited this behaviour from becoming a subject worthy of investigation in its own right. Crawford, for example, prefers to take a broader and simpler definition of workplace bullying as 'an aggressive act and as aspect of violence' (Crawford, 1999:88) thereby subsuming bullying and all forms of workplace harassment or coercion under the umbrella term of 'violence'. Similarly, while recognising certain distinctive features of sexual harassment and bullying, Hearn and Parkin (2001) see both behaviours as forms of organizational 'violation'. However, these broad definitions may fail to capture the complex nature of bullying and the many different tactics used.

In response, some researchers notably McMahon (2000) have attempted to make a distinction between bullying and other types of harassment. McMahon cites Field (1997) and research undertaken by the Manufacturing Science Finance union $(1994,1995)$ to underline her preferred distinction:

“... essentially bullying is an abuse of power. Bullying can, but does not always, involve physical violence. It may involve verbal intimidation, the undermining of the victims' professional work and the bully taking credit for other people's work. Harassment, on the other hand, appears ... to be orientated at some personal characteristic of the victim... i.e. sexual based on sex, racial based on race and sectarian based on religion.” (McMahon, 2000: 384)

Both harassment and bullying concern unwanted behaviour which causes offence to the targeted individual and which is not justified by the working professional relationship. This behaviour could be considered as harassment when directed against someone 
because of their race, sex, disability, age, sexual orientation or some other physical group oriented feature. Yet it might be considered as bullying when based on 'individual' factors such as personality traits, work position or levels of competence in the job. Sexual harassment therefore will be oriented towards the gender of the target and may include inappropriate touching, sexist or obscene language, derogatory/sexist jokes, use of pornography and/or sexual advances. As such, sexual harassment may well involve a physical element. Bullying on the other hand is likely to be work oriented (Hearn and Parkin, 2001) and, as Field (1997) suggests, may be psychological, rather than physical, in nature. Bullying therefore may include unfair criticism, being overruled/ignored/isolated, excessive monitoring, plagiarism, being overburdened with work or being subject to unnecessary disciplinary action (BullyOnLine, 1999).

While the above goes some way towards providing a useful distinction between the two forms of behaviour, there are overlaps and interrelationships between them. Both, for example, are likely to involve the abuse of power - though the derivation of such power may vary. Sexual harassment has been seen as being based on gendered power (e.g. Cockburn, 1991; Collinson and Collinson, 1996) so that key organizational contexts may include the position and number of women in the organization. Work on bullying, on the other hand, has tended to locate such behaviour within organizational power (Hearn and Parkin, 2001; Carr, 2000) leading some researchers (e.g. Field 1997) to suggest that bullying is not gender issue. Key contexts for bullying include organizational change, cultures of competition and uncertainty (Hearn and Parkin, 2001; Kerfoot and Whitehead, 1998; Lewis, 1999). However, some harassment may involve bullying behaviour as 
described above. Equally, bullying may involve the targeting of some 'personal characteristic' of the victim, such as gender, and therefore include sexual harassment.

Given these overlaps and interrelationships, together with the associated difficulties of drawing a clear line between the two forms of behaviour, it may be more fruitful to claim certain tendencies within each rather than focus on attempts to define particular characteristics. For the reasons outlined above, such characteristics are unlikely to be completely categorical and so trigger definitional problems that may be difficult (and unproductive) to resolve. Rather, there may advantages in accepting a degree of overlap while at the same time identifying particular trends within each behaviour type. From the above work on bullying and harassment, the following tendencies emerge:

\section{Bullying tendencies}

located in organizational power

based on individual characteristics

work oriented

key organizational contexts:

restructuring, downsizing

psychological in nature

examples:

work overload, unfair criticism,

excessive monitoring,

\section{Sexual Harassment tendencies}

located in gendered power

based on group characteristics

group characteristics oriented

key organizational contexts: gender

mix, gendered hierarchies

physical in nature

examples:

touching, sexual advances

By identifying tendencies we have moved away from subsuming bullying under harassment so it becomes more visible and worthy of study in its own right. At the same time we have avoided some of the dangers of compartmentalisation, such as a failure to highlight the similarities and interconnections between the two forms of behaviour. The 
nature of these similarities and interconnections (e.g. between organizational and gendered power) will be further explored in this paper.

\section{Previous Research}

By recognising the possibility of interrelationships between harassment and bullying, we can draw on the more extensive harassment literature, as well as on the more limited work on bullying, for potential frameworks and conceptual developments. Such research indicates that both organizational and individual factors are important influences which either inhibit or encourage bullying and harassment behaviour in the workplace (e.g. Lucero, Middleton and Valentine, 2001).

Studies that examine organizational contexts have found the occurrence of such behaviours to be related to power relations and conflicts, uncertainty and change as well as to organizational norms and culture. Thacker and Ferris (1991) and Thacker (1996), for example, see power inequalities and the desire to assert authority and dis-empower the target, as prominent organisational factors that contribute to harassment. With reference to bullying, Carr (2000) and Hearn and Parkin (2001) suggest that an overly competitive culture, excessive workloads and constant change can lead to a negative work environment that may harbour bullying behaviour. Similarly, Kerfoot and Whitehead (1998) and Lewis (1999), examining the further education sector, see intensified and uncertain work conditions, now typified in new organizational forms, as underlying factors in oppression and bullying. In a different vein, Brown (1997) discusses the 'narcissistic organization' whereby the need to preserve organizational self-esteem leads to a distorted view of negative situations and the likelihood that aggressive 
behaviour goes unrecognised or challenged, while Gabriel (1998) suggests that insults, a common form of bullying, are part of an organizational political process that establishes lines of domination and subordination as well as grades of status and power.

Other work makes links between organizational contexts and individual predispositions. Drawing on literature on coercion, communication, cognition and learning, and referring specifically to harassment, O'Leary-Kelly et al (2000) see harassers as decision makers who choose particular behaviours in order to reach 'some valued personal goal' and where such behaviour is supported within specific organizational contexts. Aggression may be exhibited because the actor has learned that it feels good (an emotion goal) or prompted because of a perceived injustice such as the belief that a female co-worker is violating traditional sex-role expectations, a situation that is seen to demand retribution (an instrumental goal). The authors hypothesise that the choice of harassing behaviour, and the target's response, are influenced by social conditions and situational factors such as the organisational culture, organizational norms and disciplinary systems. For example, conditions in the work environment may encourage dehumanisation of certain groups or individuals or a non-perception of the harm of harassment (also see BowesSperry and Powell, 1998). Similarly, other research (Knapp et al, 1997; Seligman, 1974; Weiner, 1983, 1985; Thacker, 1992; Tedeschi and Felson, 1994) has demonstrated that a target's response to harassment, such as passivity rather than complaint, is affected by the social and organizational conditions under which the harassment takes place. Targets are less likely to complain, and the harassment to continue, if the harasser has organizational 
power, if the target has traditional sex role attitudes and if previous complaints or resistance have met with little organizational support.

The above studies imply a probable difference in the way that the genders perceive, experience and respond to an organisation's social conditions, since it is acknowledged that women tend to occupy less powerful positions in organizations than men. Burns (1995) and Pryor and Day (1988) suggest gender related differences exist in the perceptions of and responses to sexual harassment on the grounds that men have a broader definition of appropriate socio-sexual behaviour and that perceived or real powerlessness on the part of women militates against direct action to stop the behaviour. For example, Collinson and Collinson (1996), in a study of sales staff in an insurance company, found that sexual harassment of women was seen by many men as 'just a bit of fun' and a normal part of working life. The same study concluded that women pioneers, working in male dominated organizations, are more likely to experience sexual harassment and that harassment of women is likely to take more extensive and aggressive forms in male dominated than in more traditional forms of female employment. Similarly, Barling et al (1996) suggests that while women minority workers are more likely to suffer harassment, they are less likely to report bullying or harassment behaviour.

On a more sociological level, and with a specific focus on sexual harassment, LengnickHall (1995) discusses several theoretical gender based approaches. The gender approach sees sexual harassment as a likely outcome of interactions between men and women at 
work as exemplified by the contact hypothesis. This suggests that the greater the work related contact between men and women, the more sexualised the work environment and the greater the frequency of harassment. The role approach, as exemplified in the sex role spillover theory (Gutek and Morasch, 1982), sees sexual harassment as resulting from inappropriate carry-over of sex based behavioural expectations (e.g. the perception of women as wives and lovers) into the organization. Finally the power approach frames sexual harassment as a mechanism for maintaining economic and political superiority of men over women. Gutek (1985) for example sees sexual harassment as an attempt by men to secure their dominant position by emphasising the 'woman-ness' of their female co-workers and subordinates; and Summers et al (1989) suggest that sexual harassment may reflect men's attempts to present a strong masculine identity and strong social power at work. This view is supported by Cockburn (1991) who argues that sexual harassment is a male intervention for the assertion of power and a warning to women 'intruders' into the workplace.

Such issues of power, control and change are particularly pertinent to higher education. Commenting on the rise of bullying in the sector, Lewis (1999), for example, found a general agreement amongst higher education employees that "the increasing pressure on public sector organisations" (Lewis, 1999: 108) was to blame. Pressures on management were then passed 'down the line' to all members of staff, contributing to an 'academic machismo' (Brewis and Grey, 1994) as academic and support staff struggle to meet demands for increased efficiency. Contributory factors also included the increasing presence of short-term and temporary contracts, a power imbalance between managers 
and academics, and a lack of well-trained senior and middle managers. Various articles and reports, most notably the Bett Report (2000), support Lewis's contention that UK institutions of higher education are, structurally and organisationally, arenas of considerable and increasing inequalities in terms of pay, contractual arrangements, conditions of work and hierarchical position. Part of this inequality is based on gender: women occupy one third of all UK academic posts and less than one tenth of senior positions (HESA, 1999/2000). They have also been concentrated in less secure posts, often on teaching or research- only contracts and paid, on average, less than their male colleagues (AUT, 2000).

\section{Project Aims}

Against this background, the overall aim of the research project was to investigate the nature and experience of bullying within the higher education sector and to explore differences by gender. A further focus was on how organizational contexts may have contributed to the bullying that was taking place. The project had the following specific objectives:

- to investigate gender differences in the form and the effects of bullying

- to assess how perceptions of bullying might vary between men and women

- to explore individual experiences of bullying and to locate those experiences within specific organizational contexts.

- to reflect on the implications of the above for furthering our understanding of the interrelationships between bullying and sexual harassment 


\section{Sample and Methodology}

The research was conducted in two stages.

In stage one, and with a specific focus on the first two research questions (the prevalence and form of bullying; the perception of bullying), a questionnaire survey was conducted at a single university in the UK. This stage of the research was conducted by the Association of University Teachers (AUT) and with the full consent of the university in question. One thousand nine hundred questionnaires were sent out to every member of staff on the payroll, at each of the university's sites. A total of 378 staff responded to the survey, a response rate of $19.8 \%$. The survey covered administrators, senior managers, all levels of skilled and unskilled staff, as well as academics. The questionnaire, which was devised by the regional office of the AUT in close association with the local AUT branch, was in three parts. Part 1 sought information on the personal experience of bullying and/or the witnessing of bullying (e.g. the form and the effect of bullying, the relationship between bully and victim, the number of people involved). Part 2 related to awareness of policies on bullying and whom respondents would approach if bullied, while part 3 requested some personal information (e.g. gender, contractual type, length of service). After initial examination by the AUT, questionnaires were passed to the authors for more detailed analysis. Data was mainly nominal so the two sample chi-square test was used as appropriate for comparing two groups (male/female) on a nominal scale - the $\mathrm{P}$ value indicating the existence of significant differences between the two groups. 
In addition to statistical data, the survey solicited textual, autobiographical data by asking for respondents' comments upon their experience of bullying. This allowed respondents to add further information and observations, mainly in relation to the second research question i.e. the perception of bullying. Comments were collated and analysed for patterns, trends and gender differences.

In stage two, following the questionnaire survey and independently of the AUT, staff from this and other universities and higher education institutions were interviewed. This part of the study addressed the third research question namely targets' experiences of bullying within specific organizational contexts Respondents were asked to relate the circumstances under which they were bullied, the form that bullying took, the possible motivation of the bully and their coping strategies. Potential respondents were found through personal contacts and through 'word of mouth' - the sensitive nature of bullying precluding a more 'open' sampling method. Three women and two men came forward from four different institutions. Two of the women were academics and one was a clerical worker. One of the male interviewees was a technician and one was director of marketing on the senior management team. Interviews were taped and transcribed in full and the data analysed with the aim of building theory inductively in a manner informed by Glaser and Strauss's concept of grounded theory (Strauss and Corbin, 1990). Framework analysis, a model which has emerged from grounded theory, was used to identify themes and issues that emerged from the data. As outlined by Ritchie and Spence (1996), this involves a systematic process of sifting, sorting and charting material according to key issues and themes. The researcher draws on a-priori issues informed by 
the original research questions, emergent issues raised by the interviewees themselves and analytical themes arising from the recurrence or patterning of particular views and experiences. Accordingly, the coding process was informed by the interview themes discussed above, by issues raised by targets of bullying and by themes which emerged after reflections by the researchers.

\section{Results}

\section{The questionnaire survey}

Of the 378 questionnaires that were returned, two thirds were from women. Just over a quarter of the sample had experienced bullying and a third had witnessed bullying at work. In both cases, there was a significantly higher proportion of women: $28.5 \%$ of women had experienced bullying compared with $19.8 \%$ of men; $67.5 \%$ of women had witnessed bullying compared with only $29.4 \%$ of men. No action was taken in three quarters of cases where the bullying had been reported either formally or informally. In eight out of ten cases, bullying was perpetrated by the individual's manager and in only one fifth of cases was the bully on the same grade of seniority as the target.

The most common form of bullying was unfair criticism, experienced by two thirds of those who had been bullied. This was followed by intimidation (55.6\%) and humiliation (46.5\%). Other prevalent types of bullying were verbal abuse, withholding information and excessive monitoring. Women were significantly more likely than men to have their decisions overruled $(\mathrm{P}=0.018)$. They were also more likely to encounter verbal abuse and the withholding of information - though gender differences were not significant. The witnessing of bullying followed a similar pattern with unfair criticism, intimidation and 
humiliation as the most common forms of bullying behaviour. There were no gender differences in this respect.

\section{Insert Table 1}

The most common effects of bullying were loss of confidence, anxiety and loss of selfesteem. Men were more likely than women to experience loss of confidence, nausea/sickness, depression, loss of appetite $(P=0.007)$ and loss of sleep $(P=0.085)$. Women were more likely to have headaches, suffer anxiety, and experience memory loss - though gender differences were not significant.

\section{Textual Comments}

Approximately one quarter of all respondents wrote comments at the end of their questionnaires. Two thirds were written by women. Comments gave some indication of how men and women perceive and explain bullying. Some men (but no women) denied the existence of bullying in the institution. As one man commented, "in 44 years of academic life I have never witnessed or heard of an act of bullying". Another was critical of the distribution of the questionnaire, declaring: "We're not kids".

Comments by men indicate a tendency to locate bullying behaviour within the larger context of local and national higher education issues and to see such behaviour as part of a (strong) management technique. The Research Assessment Exercise, the requirements of the Quality Assurance Agency and the "cut and thrust" of departmental life were cited 
as underlying reasons for what was generally seen as a rise in bullying. One man commented:

"I think nearly everybody in the university is aware of greater pressure on staff which has led to more aggressive management, which taken too far could certainly be considered as bullying”.

For some men, this was a necessary part of university management:

"A manager is actually taking the bull by the horns and trying to resolve problems. If we get to the stage where anyone can claim 'bullying'... for any actions, then God help us".

Rather than focusing on university structures and procedures, women commented on their experiences in a more autobiographical and personal way. One woman wrote, for example, that she felt "stupid and inadequate", another that she felt "devalued" and "heading towards burnout" while a third described her day to day life as "unbearable". Women placed their own experience in a sequence of events and emotions. This is captured by the following quotes:

"(I got) treatment from my GP in the form of anti-depressants and beta blockers ... Although I reported the bullying to a higher manager and Personnel verbally I felt unable to put my concerns in writing for fear of reprisals”.

"I phoned the person concerned (the bully) and said I wanted an appointment. She said she wanted to know NOW what I had to say. When I explained how I felt, she said I was ...irrational. She was angry. I tried to explain that I simply needed to tell her that I was stressed and unhappy in this working relationship..." 
Overall, textual data suggests that men were more likely than women to perceive bullying as a particular management style within the wider organizational context of higher education. Women, by contrast, tended to address the personal and emotional consequences of bullying behaviour.

\section{Interview Results}

We present below brief scenarios of each bullying situation so that analysis and discussion of interview data can be put in context.

Jane, a new lecturer, was bullied by a more senior, female member of staff who had appointed herself as 'unofficial' mentor during Jane's probationary period. The bully gave her useless but time-consuming tasks (e.g. putting all modules on a web site for a degree that was to be replaced in six months) and was openly critical of her work. Fearful that the bully's attitude and behaviour towards her might cause her to fail her probation, Jane took steps to ensure that she had a witness present when the bully inspected her class and that she had full evidence of work completed for her probationary review. Jane eventually complained (informally) to her head of department. She is no longer a target of bullying though bullying behaviour continues in the department.

Mary was an established academic in another discipline but, as a recently appointed member of staff in a new field, was put on probation. Mary experienced two periods of bullying. The first period started when, recently separated, she rebuffed the sexual advances of her head of department and bully in question. Her head of department was 
also her mentor and Ph.D. supervisor. Bullying took the form of verbal abuse, appropriation of work and unfair treatment. Mary failed her promotion and was put on an annual contract. She lodged a formal complaint through the union, which was upheld and the bully left the university. She was then bullied by her new head and deputy head of department who saw her as a trouble maker and who tried to gather evidence from staff and students to discredit her - at one point instigating a public investigation into alleged mishandling of research accounts. Mary rebutted each charge with documentary evidence. She eventually found a position at another university where she now has a personal chair.

Susan worked as an administrator in the finance department of her university where she was bullied be several of her female peers. She and her bullies had worked together amicably under one team but a restructuring meant Susan had a different (and better) manager. She had more interesting work and had greater access to resources such as training and staff development. Susan was ostracised by members of her previous group even though they still worked on common projects - and was subjected to a "whispering campaign' of verbal abuse. Susan complained (informally) to her male line manager but no action was taken. She moved to a different job within the university.

John was director of marketing and was bullied by his female line manager (the viceprincipal) after a period of stress related illness and absence from work and after the institution in question received an unsatisfactory inspection report. Bullying took the form of unfair criticism, excessive monitoring and removal of responsibilities including 
the transfer of his team to a different manager and exclusion from all committees on which he had previously served. John made a formal complaint through his union. He eventually took voluntary severance.

Steve worked as a technician and was bullied by his head of division who was under pressure from senior managers to improve performance. Bullying took the form of unfair criticism, excessive work demands and verbal abuse. He made a complaint, with several others, to personnel. Allegations were not upheld and the bully has remained in his post. However, the worst aspects of the bullying stopped. Steve still works in the department.

The table below summarises the five cases:

\begin{tabular}{|c|c|c|c|c|}
\hline & $\begin{array}{l}\text { Gender of bully } \\
\text { Relationship } \\
\text { with target }\end{array}$ & Form of bullying & Target response & $\begin{array}{l}\text { Precipitating } \\
\text { factors }\end{array}$ \\
\hline $\begin{array}{l}\text { Jane } \\
\text { New lecturer }\end{array}$ & $\begin{array}{l}\text { Female bully } \\
\text { Mentor } \\
\text { (unofficial) }\end{array}$ & $\begin{array}{l}\text { Unfair criticism, } \\
\text { work overload, } \\
\text { allocation of useless } \\
\text { tasks }\end{array}$ & $\begin{array}{l}\text { Informal } \\
\text { complaint to head } \\
\text { of department } \\
\text { (female) }\end{array}$ & $\begin{array}{l}\text { New member of } \\
\text { staff } \\
\text { Probation } \\
\text { Break-up of } \\
\text { relationship }\end{array}$ \\
\hline $\begin{array}{l}\text { Mary } \\
\text { New lecturer }\end{array}$ & $\begin{array}{l}\text { Male bully } \\
\text { Head of } \\
\text { department (also } \\
\text { mentor and } \\
\text { Ph.D. } \\
\text { supervisor) }\end{array}$ & $\begin{array}{l}\text { Verbal abuse, sexual } \\
\text { advances, } \\
\text { appropriation of } \\
\text { work, unfair } \\
\text { treatment }\end{array}$ & $\begin{array}{l}\text { Formal complaint } \\
\text { to union (first } \\
\text { period). } \\
\text { No action (second } \\
\text { period) }\end{array}$ & $\begin{array}{l}\text { New member of } \\
\text { staff } \\
\text { Probation } \\
\text { Break up of } \\
\text { relationship } \\
\text { Rejection of bully's } \\
\text { sexual advances }\end{array}$ \\
\hline $\begin{array}{l}\text { Susan } \\
\text { Finance officer }\end{array}$ & $\begin{array}{l}\text { Female bullies } \\
\text { Peers/work } \\
\text { colleagues }\end{array}$ & $\begin{array}{l}\text { Ostracism } \\
\text { Verbal abuse }\end{array}$ & $\begin{array}{l}\text { Informal } \\
\text { complaint to line } \\
\text { manager (male) }\end{array}$ & $\begin{array}{l}\text { Transfer to a better } \\
\text { managed work } \\
\text { group. } \\
\text { Restructuring }\end{array}$ \\
\hline $\begin{array}{l}\text { John } \\
\text { Director of } \\
\text { Marketing }\end{array}$ & Female bully & $\begin{array}{l}\text { Excessive } \\
\text { monitoring, removal } \\
\text { of responsibilities, } \\
\text { unfair criticism }\end{array}$ & $\begin{array}{l}\text { Formal complaint } \\
\text { to union }\end{array}$ & $\begin{array}{l}\text { Absence through } \\
\text { illness } \\
\text { Unsatisfactory } \\
\text { inspection }\end{array}$ \\
\hline $\begin{array}{l}\text { Steve } \\
\text { technician }\end{array}$ & $\begin{array}{l}\text { Male bully } \\
\text { Director of } \\
\text { division }\end{array}$ & $\begin{array}{l}\text { Verbal abuse, unfair } \\
\text { criticism, work } \\
\text { overload }\end{array}$ & $\begin{array}{l}\text { Formal complaint } \\
\text { to personnel }\end{array}$ & $\begin{array}{l}\text { Pressures on the } \\
\text { department to } \\
\text { improve } \\
\text { performance }\end{array}$ \\
\hline
\end{tabular}


Several themes emerged from the interview data. Firstly, a close association between bullying and power emerged from all the interviews. In four of the five cases interviewees were bullied by more senior personnel (three of whom were line or higher managers) and in the fifth case (Susan) power was exercised through the bullies' numerical advantage. Where bullies were more senior, they used their positions to disempower the target and often forced targets to confront their powerlessness through acts that contravened any sense of justice or fair play. Mary's bully, for example, used his power as her line manager and Ph.D. supervisor to force her to publish articles in his name and to hand over a research grant that she had been provisionally awarded but which needed departmental approval before final confirmation could be made. Mary commented on her powerlessness in this situation:

"I said you can't do that and he said can't I? I'm your head of department, I'm your mentor for your probationary period, I'm the supervisor for your Ph.D. - if you don't let me have it (the research grant) you are not going to get anything. In fact you may not get anything anyway." (Mary: academic)

Two days later, Mary was told she had failed her probation and was put on a temporary contract.

Jane, John and Steve were made to do useless tasks that they and their bullies knew were meaningless. John, for example, on his return from sick leave and having been excluded from meetings with other members of the senior management team, was told to consult with junior staff before writing a planning document: 
"Like previously (i.e. before sick leave) I would sit on every committee - I was removed from that and attended no meetings at all! Previously the heads of school were always popping to ask my advice about this and that - now I saw nobody. And all of a sudden she wanted me to go into massive consultation - with staff that were junior to me - and I saw that demand for consultation as an attempt to belittle me. They had nothing to say because they knew nothing of the issues...It was a complete waste of time”. (John: Director of Marketing)

Interviews also suggest that power can be more effectively wielded - and that bullying can intensify - when targets are vulnerable or alone. In Jane and Mary's case, bullying escalated after they separated from their partners. John was bullied after a period of illness that he felt contributed to the treatment he received. As he became stronger bullying decreased:

"If I had not been ill, the bullying would not have taken place. She would not have been able to do it. I would have met her head on. But at first I didn't - I was vulnerable and I didn't really feel up to it. She was trying it on because I had been off - she could see that I was vulnerable... and then when I started to fight back, she kind of retreated into behaving properly". (John: Director of Marketing)

Such power and control may also involve a sense of ownership - an issue that was raised by both Steve and Mary as they discussed the nature of the bullying relationship. For Steve, power and ownership were closely linked:

"I find it difficult to understand why people bully - the power thing is definitely there. They think: I'm in charge of you and you do what I say, you belong to me" (Steve: technician) 
Mary's reflections on the reactions of her bullies to the news that she was leaving raised a similar issue:

" it (the bullying) opened a dimension of hell that I never thought was possible. The grief they displayed when they realised I had got out from under was the worst aspect - that, the bullying, was the way they wanted it to be. (They said) how could you do this to me, how could you leave me?... But their emotions - the grief because I should have been theirs" (Mary's emphasis)

Interactions of power and control were acted out within specific organizational contexts. At this level, a second theme concerns how hierarchies and officially sanctioned procedures and processes can influence the form of that relationship and can facilitate the concealment of aggressive intent. A critical factor here is the hierarchical position of the bully in relation to the target. If, as is likely to be the case, the bully is more senior, interviews suggest that structures that may be designed in part to protect and support staff (mentoring systems, research supervision) or to promote flexibility (probationary periods, temporary contracts) can be captured and subverted by bullies to meet radically different ends from the ones originally intended. Consequently, supervision and care associated with mentoring can be used to act out and conceal unfair criticism and/or unnecessary work demands and to create fear over the possibility of failing probationary reviews. This was particularly evident in the cases of Jane and Mary, who were both on probation during their bullying experience and who were bullied by their mentors. Jane commented on her own situation:

"She (the bully) was not my line manager - but there was an issue where the head of department behaved as though this woman was my line manager...she was 
initially designated as my mentor, though not officially, and she was senior to me. So she was involved in all key decisions affecting my future and was asked for advice as to my competence". (Jane: academic)

Jane recalled the outcome of the first in a series of interviews running up to her probationary review. Despite being conducted in the presence of the head of department, who at that time was not aware that bullying was taking place, the interview was used by Jane's bully to intimidate her:

"A week before it (the probationary review) was due, I got an email from the head saying WE want to see you - so she (the bully) was going to be there as well. And in the interview, with the head, she started grilling me about my performance saying she wanted to see evidence of the work I had done to date. And this was a week before it was due - it was such a pressure on me..and she said I will come and look and watch you do a session. I felt so insecure. I felt she was out to get me and I felt that was it..I'd fail.." (Jane: academic)

Mentoring, a system that is designed to help and support staff during a probationary period, can therefore be subverted by the bully to further his or her intimidation of the target. Similarly, the close relationship associated with Ph.D. supervision can give the bully the opportunity to misappropriate work (as in Mary's case) as well as to abuse the target. Mary described the nature of her one-to-one meetings with her bully and Ph.D. supervisor:

"As my supervisor we had weekly meetings. I had to come - because that was the way the Ph.D. was being supervised. That was sheer bloody torture. He would say 
- everyone's complaining about you, you have a very sick personality, you are manipulative, you deliberately do things to provoke me..." (Mary: academic)

When Mary failed her probation, her head of department (and bully) put her in a temporary contract. Mary recalled the meeting that decided her future in this matter:

"I was called to the probationary panel... and they said - we are recommending that your probationary appointment be terminated and if you want a job at this university you have to come to terms with your head of department...he has some ideas about how to deploy you. So they walked out (of the meeting) and he (the head of department) said 'Now I think we are on the right footing - now we can work together. You can write all my publications and I will put you on a yearly rolling contract which will be renewed if you do as I say'." (Mary: academic)

More generally, bullying can be concealed under a perceived need for 'strong' managerial control. Demands from university management for improved performance in Steve's division and an unsatisfactory inspection at John's institution had put their bullies under extreme pressure to deliver certain results. As Hearn and Parkin (2001) suggest, such pressures can contribute to bullying behaviour under the guise of a directive management style. This was illustrated by John's situation, where bullying took place during fortnightly meetings with his line manager (and bully in question):

"It was normal for her to have quite strictly controlled meetings with all the people that she managed so I expected that. So she did have this routine of have you done this, have you done that...but this constant criticism and monitoring my work... I felt I was being punished for being off. I was always at fault and all the things I had been doing well in the past I seemed to have no responsibility for and 
were written off...I found it very stressful because the bottom line was I thought she was engineering my departure." (John: Director of Marketing)

Referring to the university's failure to act over bullying allegations, Steve commented on the perceived overlap between bullying and 'strong' management:

"The university hid behind that theme (of strong management) - oh it's just people who are used to a slightly weaker hand on the tiller and now don't like the fact that somebody is directing what they are doing.." (Steve: technician)

Therefore, management hierarchies and the supposed need to oversee and control work performance can be used to legitimise and conceal tactics of excessive monitoring, disempowerment and isolation (John) as well as unfair criticism and intimidation (Steve). This suggests that official structures and procedures (managerial authority and lines of command, mentoring responsibilities, the probationary review process) can be captured and subverted by the bully to further their power and control and can help to conceal the tactics used.

A final theme concerns the response of targets to the bullying they encountered. Some gender differences emerged in this respect. All targets had coping mechanisms based on eliciting outside support. Both men made formal complaints to their trade union and/or personnel while Susan and Jane made informal representations to their managers. Mary also made a formal representation to her union though, in her second period of bullying, she took no action either formally or informally in this respect. One possibility (though the small sample size suggests caution in this respect) is that men may be more likely to 
report bullying formally to an outside agency while women elicit informal support. A further possible gender difference concerns speed of response. Both men dealt with the bullying situation swiftly (neither John nor Steve allowed the bullying to continue beyond six months) while Jane and Susan endured bullying for over a year and for Mary the bullying, with different perpetrators, lasted for several years. Finally, men may be more likely to take direct action to confront the bully. As well as initiating action through outside agencies, both Steve and John 'went on the offensive' and challenged their bullies over accusations made or decisions taken. Steve strongly refuted, to the bully's face, allegations of negligence while John, at every meeting, challenged his manager over her decision to remove from him the responsibility for his team. By contrast, women may prefer a self-defence strategy designed to outwit the bully in terms of specific tactics used. Accordingly, Jane had evidence at her probationary review of all work produced to date and ensured a witness was present when the bully inspected her class:

"I said to my colleague - look can you come in (to my class) and be there, so that you can act as witness? But we had to have a rationale - so I built him into my module! So basically, at the end of it I went back and had another joint meeting with her and the head of school and there was nothing she (the bully) could say against me”. (Jane: Academic)

In a similar 'defensive' tactic, Susan tried to thwart her bullies by pretending that their behaviour (of isolation and exclusion) had no effect on her, rather than relying on a more confrontational approach

"I used to go home in tears and wake up in the morning and dread going to work - and that made me more determined to let them know you're not getting to me... 
I suppose I should really have opened my mouth and said something but I didn't feel that confident”. (Susan: Finance Officer)

Mary produced documentation to rebut charges of financial mismanagement though, as she pointed out, such strategies could be counter-productive:

"And this is what continually happened - you have a meeting, you prove your case and then it is ignored and you go back to square one. So OK we didn't get you on this one but we will get you on that one! There's no benefit from proving that you're being bullied - it just gets worse and worse". (Mary: academic)

In fact, in none of the above cases were self-defensive strategies successful in stopping the behaviour.

\section{Discussion}

This paper set out to investigate gender differences in the experience of bullying within the higher education sector and to examine individual experiences of bullying as set in specific organizational contexts. Various differences emerged from the survey data, from textual comments and from the interviews. Firstly, differences emerged in terms of the scale, form and perception of bullying. In accordance with other work on harassment, which has suggested that women are the likely targets of violence at work (Burns, 1995; Pryor and Day, 1988), this research found women were more likely than men to be the targets of bullying. At the same time, while unfair criticism and intimidation were the most common forms of bullying, women were significantly more likely than men to have their decisions overruled. If, as Gutek (1985), Miller (1997), Cockburn (1991) and Summers et al (1989) suggest, male aggression towards women in the workplace is often motivated by a desire to dis-empower and control, then overruling decisions is a public 
and potentially powerful strategy - more powerful perhaps than unfair criticism or intimidation. However, this assumes that bullies are predominantly male - and we have no information from the survey on gender in this respect. In fact, research by Field (1996) suggests that women are just as likely as men to be perpetrators in bullying situations.

Gender differences also emerged in the perception of bullying. As with other work on harassment (e.g. Gutek, 1985; Thaker and Ferris, 1991; Collinson and Collinson, 1996), women were more likely than men to perceive certain behaviours as threatening or unwelcome. Men, on the other hand, tended to see bullying within a wider organizational context and/or to label it as part of a particular management technique (though interviews with men may indicate they are more willing to identify bullying when they themselves are targets). This suggests that men may have a broader interpretation of what constitutes acceptable behaviour. This difference can have potentially serious consequences. If, as the present survey suggests, women are more likely than men to approach their managers to report bullying, and if managers are likely to be male, then it may not be surprising that in the majority of (formally and informally) reported cases, no action is taken. Susan's attempt to get help from her manager is a case in point. Furthermore, if men see such behaviour as less serious, they are unlikely to intervene in any capacity. The low number of men compared with women who claimed to have witnessed bullying may indicate not so much the absence of such behaviour, as a lack of recognition (i.e. a tendency to see bullying as some other, less serious type of conduct) on their part. Work on so-called 'bystander-intervention' has suggested that in any situation (e.g. accidents and emergencies) intervention depends on the extent to which people interpret the 
situation as serious (Shotland and Straw, 1976; Shotland and Stebbins, 1980). In a similar vein, harassment literature has suggested that observers are more likely to intervene if they see the circumstances as problematic (Bowes-Sperry and O'Leary Kelly, 2001). In this context, if men are less likely to perceive bullying behaviour as cause for concern, then they may be reluctant to intervene with the result that bullies go unchallenged.

A final gender difference to emerge from the data concerns target response. As we have seen from the survey, women were more likely to report bullying to their managers than to personnel. In partial support of this tendency, two of the three women interviewed (Susan and Jane) reported the behaviour in this way while both men took action through the union and through personnel. This difference may reflect a desire on the part of women to elicit help or support and to avoid the confrontation that formal procedures would involve. As one woman commented on her questionnaire, "contacting personnel or the AUT may lead to retaliation and make the whole thing bigger". This may leave women with few options if, as is often the case, women are bullied by their own managers. Such reluctance is in line with Barling et al's view (Barling et al, 1996) that women who lack power, or who perceive themselves to be powerless, are unlikely confront bullies through direct action. In their typology of target responses to sexual harassment, Knapp et al (1997) suggest that 'advocacy seeking' (where the behaviour is reported to a supervisor, an internal official body or an outside agency), is the most effective strategy in ending the behaviour. This is followed by 'confrontation/negotiation' (little support from outside but where the bully is confronted directly) while 'avoidance/denial' (e.g. avoiding/ignoring the perpetrator) and 'social coping' (where 
support is sought from colleagues and friends) are least effective. As we have seen, all five targets 'sought advocacy' in some way though, with the exception of Mary's first period of bullying, the women did not do this through the formal complaints procedures. For some of the reasons discussed above, concerns over unwanted behaviour raised informally through managers can be more easily dismissed and/or ignored - suggesting that an important distinction needs to be made within 'advocacy seeking' strategies between formal and informal reporting procedures. In fact, even though the outcome of the formal process might be unfavourable, as in Steve's case, the exposure of the bully to public scrutiny may be sufficient to halt the behaviour.

As discussed above, both men (and none of the women) adopted what could be seen as the more aggressive 'confrontation/negotiation' tactics. By contrast, women preferred self- defensive strategies designed to out-wit the bully. Such a strategy is not included in Knapp's typology and is intended to thwart the bully in terms of specific tactics used, rather than stop the behaviour altogether - even though this would be the preferred outcome. While affording some temporary protection from the bully, such strategies are unlikely to halt the behaviour in the long term.

Linked to the nature of response is the timing of that response. Failure to stop bullying at the outset can have serious consequences if, as Allen and Lucero (1996) suggest, an 'escalation dynamic' exists whereby assaultive skills become enhanced through practice and experience. Accordingly, bullying behaviour is likely to escalate over time as the target becomes more vulnerable and dis-empowered and as the bully becomes more 
successful in his or her tactics. One possibility here, and one which is supported by the interview data, is that women may take longer to initiate action with the result that bullying gets worse. In terms of Knapp et al's typology above, the escalation dynamic helps to explain why avoidance/denial and social coping strategies are unlikely to be successful in stopping the behaviour and suggests that such strategies may be counterproductive as bullying intensifies with time.

So far, we have examined some gender differences in the form and perception of bullying as well as differences in target response. Other aspects of bullying, however, appear to cut across gender. Research by Field (1996) has indicated that bullies can be either sex (leading Field to conclude that bullying is "not a gender issue" - an issue taken up later in this discussion). While we have no data from the present survey on perpetrator gender, the fact that female bullies were involved in three of the five bullying situations explored in interviews goes some way to support Field's research.

The survey and interview data suggest targets are more likely to be bullied by men and women in higher hierarchical positions (e.g. managers) than by peers. A further factor that cuts across gender therefore concerns the role played by the possession of institutional power within contexts where bullying takes place. As Clegg (1989) has noted, the 'nodal position' of certain individuals within an organizational hierarchy can mean that they have privileged access to networks and discourses that allow them to "translate phenomena into resources and resources into organizational networks of alliance, of coalition, of antagonism, of interest and of structure" (Clegg, 1989: 204). 
Interviews indicate how such 'translation' takes place so that hierarchies and officially sanctioned structures and procedures can become a 'resource' for aggressive behaviour. In support of Hearn and Parkin's (2001) contention that bullying cannot be divorced from structures and hierarchies of power, bullies accordingly can use their power to capture and subvert organizational structures and official procedures to their own ends.

This challenges work suggesting that bureaucracies can prevent misuse of position and authority. As Kanter (1990) points out, structures and procedures are important because they help to minimize personal patronage and the abuse of power. Similarly, DuGay (2000) argues that rules of procedure as well as "restraints on the power of line management" (DuGay, 2000: 87) guard against corruption and help to ensure accountability as well as honesty and integrity in management activities. However, this does not rule out the possibility that individuals can subvert such structures and that consequently some behaviours can fall below the horizon of official visibility. Therefore, contrary to Weber's view that bureaucratic structures "diminish the dependency of the individual on the grace and power of the authorities" (Weber, 1978: 812), the successful capture and mis-use of such structures may actually serve to increased it.

The above discussion suggests that, while gender differences exist in the perception and experience of bullying, some aspects of bullying cut across and therefore can be divorced from gender. As we have seen, both male and female bullies can abuse organizational power to intimidate their targets. However, we would argue along the lines of Collinson and Hearn, (2000), that organizational power relations are themselves heavily gendered - 
not in terms of the gender of bodies that occupy managerial positions but in terms of the gendered nature of discursive practices and assumptions that underpin the performance of management. For example, as Collinson and Hearn point out, the managerial prerogative over key decisions remains the taken-for-granted norm and this prerogative can be seen as part of a highly masculine discourse based on power and control. At the same time, gendered assumptions can be discerned not just in those aggressive forms of management that underpin many bullying situations but also in initiatives such as performance reviews and performance targets, increasingly present in higher education, which can be linked to masculinist concerns with personal power and the ability to control. As Kerfoot and Whitehead (1998) suggest, both men and women can invest their sense of being in masculinist discourses. Rather than challenging the masculine hegemony of management, some women - particularly those who employ bullying tactics - may be conforming to the masculine ethic that underpins much of management practices. On this basis, while men and women may be involved as perpetrators in bullying situations and while, irrespective of gender, much of bullying involves the abuse power, such behaviour cannot be divorced from gender considerations.

\section{Conclusion}

In this article we have drawn from harassment and bullying literature to address the hitherto neglected area of gender and bullying. Drawing on work on harassment, we find gender differences in the scale and perception of bullying as well as in target response. We consider implications of these differences for by-stander intervention, for the scale of bullying and for the ability of targets to stop the behaviour. Drawing on bullying literature, we point to the critical role of organizational structures in understanding 
bullying behaviour. In particular we refer to the capacity of bullies to capture and subvert structures and procedures to their own ends. While some aspects of bullying may cut across gender, we locate these common factors within masculinist discourses of management. This throws some light on possible interconnections between sexual harassment and bullying behaviour. While sexual harassment is 'overtly' gendered, bullying also needs to be seen as a gendered activity - although at a different and perhaps more deep-seated level. Bullying therefore needs to be put in a gendered context in order to further out understanding of this behaviour.

This study has several limitations. The low response rate, though not surprising given the nature of the study (and the unlikelihood of the questionnaire being completed if bullying had not been witnessed or experienced) raises issues around reliability and generalisability. The difficulty of contacting and gaining the trust and agreement of subjects for interviews was also an issue; it is probable that more interviews may well have added greater breadth to the data as well as greater insights into the nature and causes of bullying. An investigation of the comparability of bullying within different organizational contexts may also shed light upon a study which has focused on workers within institutions of higher education. However, despite these and other limitations, this study has offered important insights into the gendered nature of bullying and the significance of organizational contexts in influencing bullying behaviour. 


\section{References}

Adams, A. (1992) Bullying at Work: How to Confront and Overcome it, London: Virago

Allen, R. and Lucero, M. (1996) Beyond Resentment: Exploring Organizationally Targeted Insider Murder, Journal of Management Inquiry, 5, 86-103

AUT (2000) Gender and Average Pay for Academic Staff in the UK, AUT Research Report, May

Barling, J., Dekker, I., Loughlin, C., Kelloway, E., Fullagar, C. and Johnson, D. (1996) Prediction and Replication of the Organizational and Personal Consequences of Workplace Sexual Harassment, Journal of Managerial Psychology, 11, 5, 4-26

The Bett Committee Report (1999) Independent Review of Higher Education Pay and Conditions, June

Bowes-Sperry, L. and Powell, G. (1998) Sexual Harassment as a Moral Issue in M.S. Stockdale (ed.), Sexual Harassment in the Workplace: Perspectives, Frontiers and Response Strategies, Women and Work Series, 5, 105-124. Thousand Oaks, CA: Sage

Bowes-Sperry, L. and O'Leary-Kelly, A. (2001) Bystander Intervention in Sexual Harassment, paper presented to the Academy of Management Conference, Washington, August.

Brewis, J. and Grey, C. (1994) Re-eroticizing the organization: an exegis and critique, Gender Work and Organization, 1, 2, 67-81

Brown, A. (1997) Narcissism, Identity and Legitimacy, Academy of Management Review, $22,643-686$

BullyOnLine (1999) timefield@ successunlimited.co.uk

Burns, S. (1995) Issues in Workplace Sexual Harassment, Law and Related Social Research, Journal of Social Issues, 51, 1, 192-207

Carr, P. (2000) Bullying and Harassment in the Workplace: A Practical Guide, London Chamber of Commerce, June

Clegg, S.R. (1989) Frameworks of Power. London: Sage

Cockburn, C. (1991) In the Way of Women: Men's Resistance to Sex Equality in Organizations. London: MacMillan. 
Collinson, D. and Hearn, J. (2000) Critical Studies on Men, Masculinities and Managements in M. Davidson and R. Burke (eds) Women in Management: Current Research Issues Volume 2, Sage.

Collinson, M. and Collinson, D. (1996) It's only Dick: The Sexual Harassment of Women Managers in Insurance Sales, Work, Employment and Society, 10, 1, 29-56

Crawford, N. (1999) Conundrums and Confusion in Organisations: the Etymology of the Word "Bully", International Journal of Manpower, 20, 1, 86-93

DuGay, P. (2000) In Praise of Bureaucracy, London: Sage

Field, T. (1997) 'Tim Field's Workplace Bullying Home Page', http://www.successunlimited.co.uk/worbal.html

Field, T. (1996) Bully in Sight: How to predict, Resist and Challenge Workplace Bullying. Wantage: Wessex Press

Gabriel, Y. (1998) An Introduction to the Social Psychology of Insults in Organizations, Human Relations, 5, 11, 13 - 42

Gutek, B. and Morasch, B. (1982) Sex Rations, Sex Role Spillover and Sexual Harassment of Women at Work, Journal of Social Issues, 38, 4, 55-74

Gutek, B. and Koss, M. (1993) Changed Women and Changed Organizations: Consequences of and Coping with Sexual Harassment, Journal of Vocational Behaviour, $42,28-48$

Gutek, B. (1985) Sex and the Workplace. San Francisco: Jossey-Bass

Hearn, J. and Parkin, W. (2001) Gender Sexuality and Violence in Organizations, London: Sage

HESA (1999/2000) (Higher Education Statistics Agency). WWW.hesa.ac.uk

Hoel, H. and Cooper, C. (2000) Destructive Conflict and Bullying at Work, Manchester School of Management, University of Manchester Institute of Science and Technology.

Kanter, R. (1990) When Giants Learn to Dance, London:Unwin Hyman

Kerfoot, D. and Whitehead, S. (1998) Boy's Own Stuff: Masculinity and the Management of Further Education, Sociological Review, 46, 3, 436-458

Knapp, D., Faley, R., Ekeberg, S. and Dubois, C. (1997), Determinants of Target Responses to Sexual Harassment: A Conceptual Framework, Academy of Management Review, 22, 3, 687-729 
Lengnick-Hall, M. (1995) Sexual Harassment Research: A Methodological Critique, Personnel Psychology, 48: 841-864

Lewis, D. 1999 Workplace Bullying - Interim Findings of a Study in Further and Higher Education in Wales, International Journal of Manpower, 20, 2, 106-118

Lucero, M., Middleton, K. and Valentine, S. (2001) Improving Future Responses to Sexual Harassment: Lessons from the Decisions of Labour Arbitrators, paper presented at the Western Academy of Management Conference, Sun Valley, ID, June

MacKinnon, C. (1979)The Sexual Harassment of Working Women, New Haven, CT: Yale University Pess

McMahon, L. (2000) Bullying and Harassment in the Workplace, International Journal of Contemporary Hospitality Management, 12, 6, 384-387

Miller, L. (1997) Not Just Weapons of the Weak: Gender Harassment as a Form of Protest for Army Men, Social Psychology Quarterly, 60, 1, 32-51

Manufacturing Science Finance (MSF) (1994) Bullying at Work: Confronting the Problem, London: College Hill Press

Manufacturing Science Finance (MSF) (1995) Bullying at work: How to Tackle it: A guide for MSF representatives and members, London: College Hill Press

O'Leary-Kelly,A., Paetzold, R. and Griffin, R.. (2000) Sexual Harassment as Aggressive Behavior: An Actor-Based Perspective, Academy of Management Review, 25, 2, 86-105

Pryor, J.B. and Day, J.D. (1988). Interpretations of Sexual Harassment: An Attributional Analysis, Sex Roles, 18, 405-417

Quine, L. (1999) Workplace bullying in the NHS community Trust: Staff questionnaire survey, British Medical Journal (BMJ) Vol. 318, 228-232

Rayner,C., Sheehan, M. and Barker, M. (1999) Theoretical Approaches to the Study of Bullying at Work, International Journal of Manpower, 20, 2, 11-15

Rayner, C. (1997) Incidence of Workplace Bullying, Journal of Community and Applied Social Psychology, Vol. 9, 3,199-208

Ritchie, J. and Spencer, L. (1996) Qualitative Data Analysis for Applied Policy Research, in A. Bryman and R. Burgess (eds) Analyzing Qualitative Data, London: Routledge 
Seligman, M. (1974) Depression and Learned Helplessness, in R. Friedman and M. Katz (eds.), The Psychology of Depression: Contemporary Theory and Research, Washington, DC: Winston-Wiley

Shotland, R and Stebbins, C. (1980) Bystander response to Rape: Can a Victim attract Help?, Journal of Applied Social Psychology, 10 (6): 510 - 527

Shotland, R. and Straw, M. (1976) Bystander Response to an Assualt: when a man attacks a women, Journal of Personality and Social Psychology, 34 (5): 990-000

Strauss, A. and Corbin, J. (1990) Basics of Qualitative Research. Newbury Park, CA: Sage

Summers, T., DeNisi, A. and DeCotiis, T. (1989) Attitudinal and Behavioural Consequences of Felt Job Stress and its Antecedent Factors, Journal of Social Behaviour and Personality, 4, 503-520

Tedeschi, J.T. and Felson, R.B. (1994) Violence, Aggression and Coercive Actions, Washington, DC: American Psychological Association

Thacker, R.A. and Ferris, G.R. (1991) Understanding Sexual Harassment in the Workplace: The Influence of Power and Politics within the Dyadic Interaction of Harasser and Target, Human Resource Management Review, 1, 23-37

Thacker, R.A. (1992) A Descriptive Study of Behavioral Responses to Sexual Harassment Targets: Implications for Control Theory, Employee Responsibilities and Rights Journal, 5, 2, 155-171

Thacker, R.A. (1996) A Descriptive Study of Situational and Individual Influences upon Individuals' Responses to Sexual Harassment, Human Relations, 49, 8, 1105 - 1123

Weber, M. (1978) Economy and Society, 2 vols, Los Angeles: University of California

Weiner, B. (1983) Some Methodological Pitfalls in Attributional Research, Journal of Educational Psychology, 75: 530-543

Weiner, B. (1985) An Attributional Theory of Achievement Motivation and Emotion, Psychological Review, 92, 548-573 
Table 1: The Form of Bullying Behaviour by Gender (\%)

\begin{tabular}{|l|l|l|l|}
\hline & Female & Male & Total \\
\hline Verbal abuse & 39.1 & 23.1 & 35.4 \\
\hline Unfair criticism & 58.0 & 61.5 & 60.6 \\
\hline Malicious lies & 20.3 & 26.9 & 23.2 \\
\hline Humiliation & 46.4 & 42.3 & 46.5 \\
\hline Intimidation & 56.5 & 50.0 & 55.6 \\
\hline Unrealistic targets & 20.3 & 26.9 & 23.2 \\
\hline Removing responsibilities & 20.3 & 23.1 & 21.2 \\
\hline Blocking promotion & 27.5 & 30.8 & 29.3 \\
\hline Refusing leave & 8.7 & 11.5 & 10.1 \\
\hline Overruling decisions & 21.7 & 7.7 & 19.2 \\
\hline Withholding information & 34.8 & 26.9 & 33.3 \\
\hline Excessive monitoring & 27.5 & 26.9 & 28.3 \\
\hline $\mathrm{N}$ & 69 & 26 & 95 \\
\hline
\end{tabular}

$* \mathrm{P}=0.018$ 